\title{
Green Synthesis and Antimicrobial Activities of Silver Nanoparticles using Cell Free-Extracts of Enterococcus species
}

\author{
Iyabo C. OLADIPO ${ }^{1,2 *}$, Agbaje LATEEF ${ }^{1,3}$, Musibau A. AZEEZ ${ }^{1,3}$, Tesleem B. \\ ASAFA $^{1,4}$, Taofeek A. YEKEEN ${ }^{1,3}$, Akeem AKINBORO ${ }^{1,3}$, Abiola $S$. \\ AKINWALE $^{3}$, Evariste B. GUEGUIM-KANA ${ }^{5}$, Lorika S. BEUKES ${ }^{6}$
}

\author{
${ }^{1}$ Nanotechnology Research Group (NANO+), Ogbomoso, Nigeria; \\ ${ }^{2}$ Ladoke Akintola University of Technology, Department of Science Laboratory Technology, PMB 4000, \\ Ogbomoso,Oyo State, Nigeria; xtiecoker@gmail.com (*corresponding author) \\ ${ }^{3}$ Ladoke Akintola University of Technology, Department of Pure and Applied Biology, PMB 4000, Ogbomoso, Oyo State, \\ Nigeria; alateef@lautech.edu.ng;maazeez@lautech.edu.ng; tayekeen@lautech.edu.ng;aakinboro@lautech.edu.ng; abakinwale@yahoo.com \\ ${ }^{4}$ Ladoke Akintola University of Technology, Department of Mechanical Engineering, PMB 4000, \\ Ogbomoso, Oyo State, Nigeria; tbasafa@lautech.edu.ng \\ ${ }^{5}$ University of KwaZulu-Natal, Department of Microbiology, School of Life Sciences, Private Bag X01, Scottsville, \\ Pietermaritzburg 3209, South Africa; kanag@ukzn.ac.za \\ ${ }^{6}$ University of KwaZulu-Natal, Microscopy and Microanalysis Unit, School of Life Sciences, Private Bag X01, Scottsville, \\ Pietermaritzburg 3209, South Africa; beukes@ukzn.ac.za
}

\begin{abstract}
Cell-free extracts of six strains of Enterococcus species obtained from fermented foods were used for the green synthesis of silver nanoparticles (AgNPs), which was characterized by UV-Vis spectroscopy, Fourier-transform infrared spectroscopy (FTIR) and transmission electron microscopy (TEM). The biosynthesized AgNPs were dark brown in colour having surface plasmon resonance in the range of 420-442 nm. The spherical shaped AgNPs had sizes of 4-55 nm, whose formations were facilitated by proteins as indicated by the presence of peaks 1,635-1,637 and 3,275-3,313 $\mathrm{cm}^{-1}$ in the FTIR spectra. The energy dispersive $\mathrm{x}$-ray (EDX) showed prominent presence of silver in the AgNPs colloidal solution, while the selected area electron diffraction was typified by the face-centred crystalline nature of silver. The particles inhibited the growth of multi-drug resistant clinical isolates of Escherichia coli, Klebsiella pneumoniae and Proteus vulgaris, and also potentiated the activities of ampicillin, ciprofloxacin and cefuroxime in the AgNPs-antibiotic synergy studies. In addition, the prospective relevance of the particles as nanopreservative in paints was demonstrated with the inhibition of growth of Staphylococcus aureus, Pseudomonas aeruginosa, Aspergillus niger and A. flavus in AgNPs-paint admixture. This report further demonstrates the green synthesis of AgNPs by strains of Enterococcus species.
\end{abstract}

Keywords: antibiotics, biological routes, colour change, drug-resistance, paint preservative

\section{Introduction}

Nanotechnology is a branch of knowledge that is concerned with the synthesis of particles at nano-scale level. The biological routes of synthesis of nanoparticles are important alternatives to the use of chemicals and other methods that often have toxic effects on the ecosystem (Sneha et al., 2011). The importance of nanotechnology is increasing rapidly because of the manipulation of materials at nano-scale level for different applications. Over the years, nanoparticles have been synthesized by physical, chemical and biological methods. Many nanoparticles have been synthesized using bacterial metabolites, and these include gold (Ojo et al., 2016), ZnS (Malarkodi and Annadurai, 2012), $\mathrm{TiO}_{2}$ (Malarkodi et al., 2013), silver (Rajeshkumar et al., 2013; Lateef et al., 2015a, b, c) and silver-gold alloy nanoparticles (Ojo et al., 2016).

Out of the different types of nanoparticles, AgNPs are the most effective, with good antimicrobial efficacy (Gong et al., 2007). They have been widely applied in the production of solar cells and batteries, as catalysts in chemical reactions, bio-labelling and as antimicrobials 
(Joerger et al., 2000; Magudapathy et al., 2001). It is also used in the treatment of burns, as dental materials, in textile fabrics, treatment of water, and in sunscreen lotions (Duran et al., 2007). AgNPs have been successfully synthesised using plant extracts (Kannan et al., 2013; Lateef et al., 2015d; Adelere and Lateef, 2016; Azeez et al., 2017; Lateef et al., 2016a; Lateef et al., 2016b; Lateef et al., 2016c), bacteria (Priyadarshini $e t$ al., 2013; Lateef $e t$ al., 2015a, b, c; Lateef $e t$ al., 2016d), fungi (Selvi and Sivakumar, 2012; Lateef and Adeeyo, 2015), and even spider cobwebs and paper wasp nest (Lateef et al., 2016e; Lateef et al., 2016f; Lateef $e t$ al., $2016 \mathrm{~g})$. The antimicrobial efficacy of AgNPs is due to its ability to be ionized in aqueous medium to silver ions with pronounced antimicrobial action (Choi et al., 2008). Factors that influence the antimicrobial activities of nanoparticles include dimension, morphology, type of the particles and crystallinity. As a result, there is intense investigation by researchers to synthesize nanoparticles for diverse applications.

In the current work, strains of Enterococcus species previously isolated from traditional fermented vegetable condiments and local cheese 'wara' (Oladipo et al., 2013; 2014a, b; 2015) that have probiotic potentials were evaluated for the green synthesis of AgNPs, using the cellfree extracts. The study also investigated the biomedical and industrial applications of biosynthesized AgNPs as antimicrobial agents.

The use of Enterococcus species in nanobiotechnology is at infancy as there are few reports of the use of $E$. faecalis (Chandrakanth et al., 2014) for the synthesis of AgNPs, $\mathrm{ZnO}$ nanoparticles (Ashajyothi et al., 2014), AuNPs (Ashajyothi and Chandrakanth, 2014) as well as the synthesis of $\mathrm{CdS}$ nanoparticles by marine isolate of Enterococcus sp. (RMAA) (Rajeshkumar et al., 2014). However, the present study further demonstrates the capabilities of different species of Enterococcus for the green synthesis of AgNPs. The study is the first reference to the use of E. gallinarum and $E$. casseliflavus for the synthesis of AgNPs.

\section{Materials and Methods}

\section{Microorganisms}

Six strains of Enterococcus species used in this study were isolated as described by Oladipo et al. (2013). They were characterized using both biochemical and molecular techniques. Molecular identification to species level was performed by $16 \mathrm{~S}$ rRNA analysis. Genomic DNA of the species were isolated and the DNA fragments were amplified; amplification was carried out in a thermal cycler with each reaction mixture comprising the template DNA along with master mix and primers designated as FD1 (5'AGAGTT TGATCCTGGCTCAG - $3^{\prime}$ ) forward and RD1 (5'-AAGGAGGTGATCCAGCC- 3') for reverse. The amplified products with the expected sizes were subsequently sequenced and compared with sequences in the database of National Centre for Biotechnological Information (NCBI) (BLAST, 2016). The sequences were subsequently submitted to GenBank for accession numbers.

\section{Preparation of cell-free extracts}

Brain heart infusion broth was prepared, sterilized and inoculated with fresh culture of the isolates $\left(1 \times 10^{6}\right.$ $\mathrm{cfu} / \mathrm{ml})$. The cultured flasks were incubated at $37^{\circ} \mathrm{C}$ for 72 h. After incubation, centrifugation was carried out at 4,000 $\mathrm{rpm}$ at $10{ }^{\circ} \mathrm{C}$ for $15 \mathrm{~min}$ (Lateef et al., 2015a), and the supernatants were used for the synthesis of AgNPs without further purification.

\section{Synthesis of AgNPs}

The bacterial supernatant $(1 \mathrm{ml})$ was added separately to the reaction vessel containing $10 \mathrm{ml}$ of $1 \mathrm{mM}$ silver nitrate $\left(\mathrm{AgNO}_{3}\right)$ and placed under sunlight for the photoactivation of silver to aid the synthesis of AgNPs. The formation of AgNPs was monitored through visual observation of change in colour, and measurement of the absorbance in the range of $270-800 \mathrm{~nm}$ on a UV-Visible spectrophotometer (Genesys 10 UV Thermoelectron Corporation, UK).

The fingerprints of biomolecules responsible for the formation of AgNPs were elucidated using Fourier transform-infrared (FTIR) spectroscopic analysis (BUCK M530 Spectrophotometer, Buck, USA) on the powder sample of AgNPs as previously reported (Lateef et al., 2015a). The morphology and size of the particles were studied using transmission electron microscope JEM-1400 (JEOL, USA) operated at $200 \mathrm{kV}$. Few drops of colloidal AgNPs were applied on the copper grid $(3.05 \mathrm{~mm})$ (Agar Scientific, Essex, UK). This was then layered with $0.3 \%$ formvar that was prepared in chloroform. After settling of the particles on the copper grid, excess fluid was removed and then air-dried for TEM viewing.

Antimicrobial activities of AgNPs

It was carried out by agar diffusion method as previously described (Lateef et al., 2015a; Lateef and Ojo, 2016), using clinical isolates of Proteus vulgaris, Escherichia coli and Klebsiella pneumoniae originally sourced from LAUTECH Teaching Hospital, Ogbomoso. Inoculum obtained as 18-h culture $\left(\sim 10^{6} \mathrm{cfu} / \mathrm{ml}\right)$ was used for the seeding of MuellerHinton agar (Lab M Ltd., UK) plates. AgNPs of different concentrations were dispensed as $100 \mu \mathrm{l}$ into wells of $7 \mathrm{~mm}$ that were bored on the plates using cork borer. This was followed by the incubation of the plates at $37^{\circ} \mathrm{C}$ for $24 \mathrm{~h}$, after which zones of inhibitions were monitored.

\section{Antibacterial susceptibility test}

The clinical bacterial isolates used were evaluated for their vulnerability to some commonly used antibiotics as previously demonstrated (Lateef et al., 2015a; Lateef and Ojo, 2016). Standard antibiotics discs obtained from Abtek Biologicals Ltd. (UK) were used. The composition of the Gram negative discs were: ofloxacin (Ofl), 5; ceftazidime (Caz), 30; cefixime (Cxm), 5; augmentin (Aug), 30; cefuroxime (Crx), 30; nitrofurantoin (Nit), 300; gentamicin (Gen), 10; ciprofloxacin (Cpr), 5. In the other hand, Gram positive discs consisted of gentamicin (Gen), 10; cefuroxime (Crx), 30; erythromycin (Ery), 5; ceftriaxone (Ctr), 30; ofloxacin (Ofl), 5; Ceftazidime (Caz), 30; augmentin (Aug), 30 and cloxacillin (Cxc), 5. The experiment was carried on Mueller-Hinton plates, where 
198

cultures were observed at $48 \mathrm{~h}$ of incubation at $37^{\circ} \mathrm{C}$. The inhibitory zones were examined and interpreted (Chortyk et al., 1993) taken cognizance of the appropriate breakpoints (Andrews, 2005).

\section{Synergistic studies on antibiotic-AgNPsmixtures}

Studies were conducted on the antimicrobial synergy between the AgNPs and some commonly dispensed antibiotics such as cefuroxime, ampicillin and ciprofloxacin. The agar-diffusion method as previously described was used (Lateef et al., 2015a; Lateef et al., 2016e). The antibiotics were dissolved in sterile distilled water to obtain concentrations of $500 \mu \mathrm{g} / \mathrm{ml}$ and $1 \mathrm{mg} / \mathrm{ml}$. Then, bacterial isolates were exposed to the antibiotics using $100 \mu \mathrm{l}$ of each antibiotic dispensed into the wells. The second part of the experiment on antimicrobial synergy was carried out by combining $50 \mu \mathrm{l}$ of the antibiotic with $50 \mu \mathrm{l}$ of AgNPs (100 $\mu \mathrm{g} / \mathrm{ml}$ ), to which the test isolates were exposed. The plates were then incubated and observed for zones of inhibition as previously stated.

Evaluation of antimicrobial properties of synthesized AgNPs aspreservative in paint

The potential preservative action of the synthesized AgNPs against bacteria and fungi was carried out through the introduction of AgNPs into emulsion paint as previously described (Lateef et al., 2015a). Commercially available white emulsion paint was procured and prepared according to the instructions of the manufacturer. The paint was dispensed as $19 \mathrm{ml}$ in McCartney bottles and autoclaved at $121^{\circ} \mathrm{C}$ for $15 \mathrm{~min}$. Thereafter, the paints were inoculated with $1 \mathrm{ml}\left(\sim 10^{6} \mathrm{cfu} / \mathrm{ml}\right)$ of $18 \mathrm{~h}$ broth cultures of $S$. aureus and $P$. aeruginosa. For Aspergillus flavus and $A$. niger, $1 \mathrm{ml}\left(\sim 10^{6} \mathrm{cfu} / \mathrm{ml}\right)$ of $48 \mathrm{~h}$ culture was used. In the control, samples of emulsion paint were inoculated with the test organisms alone, whereas for the test, samples of the paint containing $1 \mathrm{ml}$ of $100 \mu \mathrm{g} / \mathrm{ml}$ of AgNPs were inoculated with the test organisms. The bottles were incubated at 37 and $30 \pm 2{ }^{\circ} \mathrm{C}$ for $48 \mathrm{~h}$ for bacteria and fungi, respectively. After the period of incubation, contents of the bottles were withdrawn and $1 \mathrm{ml}$ was plated on nutrient agar (bacteria) and potato dextrose agar (fungi) using the pour plate method. The incubation of plates was done at $37^{\circ} \mathrm{C}$ for bacteria and $30 \pm 2{ }^{\circ} \mathrm{C}$ for fungi for up to $48 \mathrm{~h}$, and thereafter checked for growth.

\section{Results and Discussion}

\section{Bacterial isolates}

The strains of E. gallinarum, E. faecium and $E$. casseliflavus used in the study were isolated from traditionally fermented vegetable condiments (iru, ogiri, okpehe, ugba) and wara. These strains were Gram-positive cocci, catalase negative, oxidase negative, and non-spore formers, with the ability to grow in the presence of $6.5 \%$ $\mathrm{NaCl}$ at $\mathrm{pH} 9.6$ and at 10 and $45^{\circ} \mathrm{C}$. The strains were able to hydrolyze esculin, pyrrolidonyl- $\beta$-naphthylamide and arginine, but were unable to hydrolyze starch. They also showed different sugar fermentation patterns. Further confirmation of identity was carried out by $16 \mathrm{~S}$ rRNA sequencing, and accession numbers assigned to each strain as shown in Table 1.

Enterococcus species are members of the family of lactic acid bacteria (LAB) that is widely distributed in nature. They have a history of being used as starter cultures in fermented foods largely due to the unique flavours that they produce, and their health-promoting activities (Oladipo $e t$ al., 2014b; Oladipo et al., 2015). Some of them may have antimicrobial activities against food deteriorating microorganisms, making them useful in food preservation (Oladipo et al., 2015). Also, different probiotic supplements, for both man and animals, include Lactobacillus and Enterococcus species (Pollmann et al., 2005; Tompkins et al., 2008; Vankerckhoven et al., 2008). To a large extent, there is dearth of information on the use of Enterococcus to produce nanoparticles. Its relevance in nanotechnology include the use of the marine isolate of Enterococcus sp. (RMAA) for the green synthesis of CdS nanoparticles (Rajeshkumar et al., 2014), and E. faecium to synthesize AgNPs (Chandrakanth et al., 2014). However, there is no report on the evaluation of E. gallinarum and $E$. casseliflavus for the green synthesis of AgNPs.

\section{Biosynthesis and characterization of $A g N P$ s}

The formation of AgNPs was characterized with the development of colour, which was produced as a result of the reduction of silver ion by biomolecules present in the cell-free extracts. The intensity of the colour increased as the bio-reduction of silver ions progressed and stabilized when the reaction was completed. The formation of AgNPs was facilitated by the cell-free extracts within a period $10 \mathrm{~min}$, with the dark brown colour which stabilized in $20 \mathrm{~min}$ as shown in Fig. 1. Several colours, including light yellow, yellow brown and dark brown, have been reported for colloidal solutions of AgNPs (Das et al., 2014; Emeka et al., 2014; Lateef et al., 2015a, b, c, d; Netala et al., 2016). The variations in colours have been ascribed to the activities of different types of biomolecules that act as bioreductants in the transformation of silver metal to nanoparticles of different sizes and shapes that affect the surface plasmon resonance of the particles. The excitation of surface plasmon vibrations in metal nanoparticles leads to the development of colour (Mulvaney, 1996).

Table 1. Enterococcus species used in this study

\begin{tabular}{cccc}
\hline Isolate code & Names of isolates & Source of isolation & Accession number \\
\hline C103 & Enterococcus gallinarum strain C103 & Ogiri & JF774410 \\
U8 & E. gallinarum strain U82 & Ugba & JF774412 \\
T10 & E. faecium strain T77 & Okpehe & JN645284 \\
T7 & E. gallinarum strain T71 & Okpehe & JF774411 \\
IP11 & E. faecium strain IP27 & Iru & JN645285 \\
W14 & E. casseliflavus strain W194 & Wara & JN645289 \\
\hline
\end{tabular}




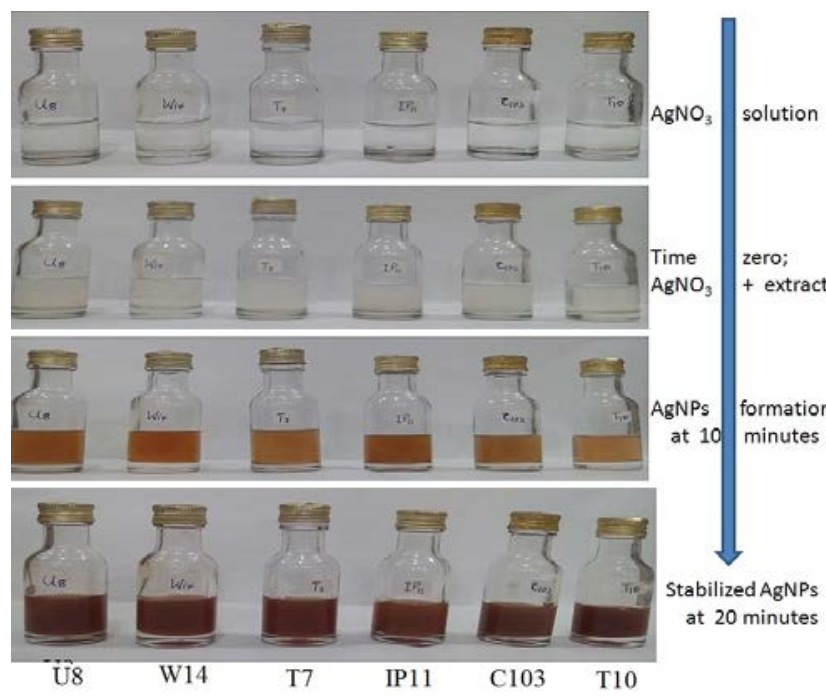

Fig. 1. Biogenic synthesis of AgNPs using cell-free extracts of strains of Enterococcus species

The UV-Vis absorption spectra of the biosynthesized AgNPs are as presented in Fig. 2. The biosynthesized AgNPs displayed surface plasmon resonance in the range of 420-442 nm, which is within the range of values previously reported for AgNPs (Shaligram et al., 2009; Kannan et al., 2013; Emeka et al., 2014; Kathiraven et al., 2015; Lateef et al.,2015b, d; Lateef and Adeeyo, 2015; Anandalakshmi et al., 2016). However, using cell-free extract of a strain of $E$. faecium, Chandrakanth et al. (2014) reported the formation of AgNPs, which absorbed maximally at $309 \mathrm{~nm}$. The particles obtained in the present study were stable without significant changes in absorption spectra when stored for about three months at room temperature.

The FTIR absorption spectra showed strong peaks at 3,305.99 and $1,635.64 \mathrm{~cm}^{-1}$ for E. gallinarum C103 cell-free extract mediated AgNPs; 3,313.71 and 1,635.64 $\mathrm{cm}^{-1}$ for $E$. gallinarum U8; $3,275.13$ and $1,637.56 \mathrm{~cm}^{-1}$ for $E$. gallinarum $\mathrm{T} 7 ; 3,309.85$ and $1,635.64 \mathrm{~cm}^{-1}$ for $E$. faecium

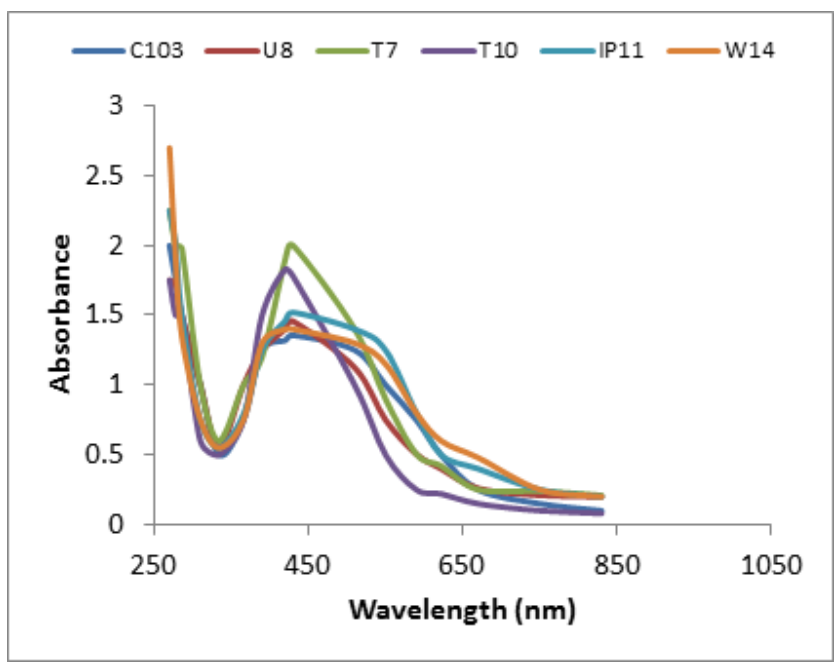

Fig. 2. UV-Vis absorption spectra of biosynthesized AgNPs

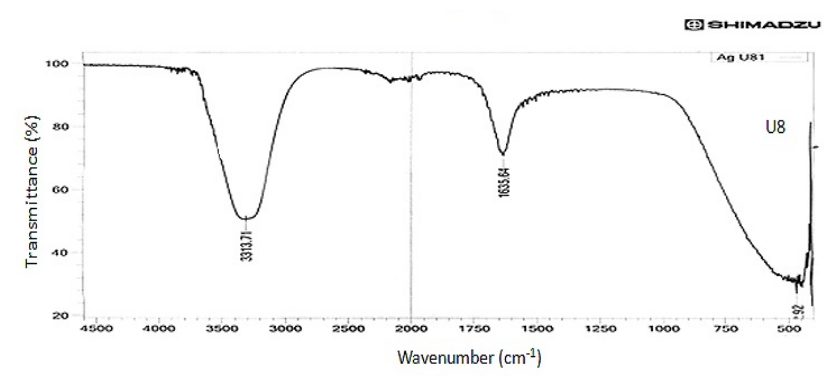

Fig. 3. FTIR spectrum of a typical biosynthesized AgNPs

T10; 3,313.71 and $1,635.64 \mathrm{~cm}^{-1}$ for E. faecium IP11; $3,304.06$ and $1,635.64 \mathrm{~cm}^{-1}$ for $E$. casseliflavus W14 cell-free extract mediated AgNPs (Fig. 3). The bands 3,275-3,313, and $1,635-1,637 \mathrm{~cm}^{-1}$ correspond to the $-\mathrm{NH} 2$ of amines or $-\mathrm{OH}$ stretch of carboxylic acid, $\mathrm{C}=\mathrm{C}$ stretch of alkenes, $\mathrm{C}=\mathrm{O}$ stretch of amides or $\mathrm{N}-\mathrm{H}$ bend of $1^{\circ}$ amine
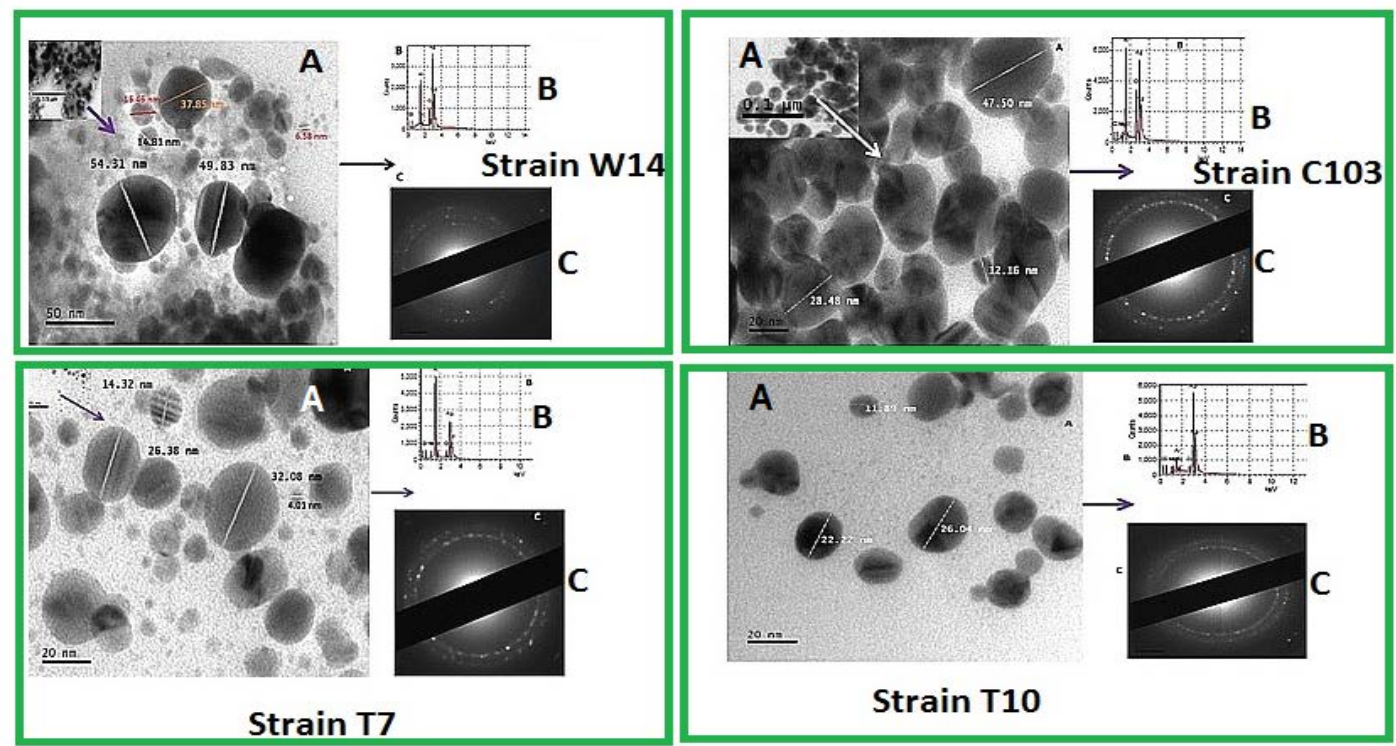

Fig. 4. Transmission electron micrographs (A), selected area electron diffraction patterns (B) and energy dispersive $\mathrm{x}$-ray signals (C) of some of the biosynthesized AgNPs 
200

respectively. This is an indication that proteinous molecules present in the cell-free extracts of strains of Enterococcus were involved in the biosynthesis of AgNPs.

Microscopic analysis using TEM (Fig. 4a) showed that the biosynthesized AgNPs were nearly spherical, having a size range of 4-33 nm for E. gallinarum T7, 5-38 nm for $E$. faecium IP11, 12-50 nm for E. gallinarum C103, 5-41 nm for E. gallinarum U8, 10-26 nm for E. faecium T10, and 5$55 \mathrm{~nm}$ for $E$. casseliflavus W14 cell-free extract mediated AgNPs. The polydispersed form of the AgNPs was corroborated by the broadness of the UV-Vis spectra as earlier presented. The EDX patterns (Fig. 4b) showed the predominant presence of silver in the AgNPs solutions with the characteristic ring-like SAED patterns (Fig. 4c) typical of the face-centered cubic crystalline structure of silver (Shameli et al., 2011; Salem et al., 2014; Shankar et al., 2014). From the foregoing, it can be concluded that the cell-

Table 2. The antibacterial activities of biosynthesized AgNPs against some bacterial isolates

\begin{tabular}{|c|c|c|c|}
\hline \multirow{2}{*}{ Isolates } & \multicolumn{3}{|c|}{ Zones of inhibition $(\mathrm{mm})$} \\
\hline & A & $\mathrm{B}$ & $\mathrm{C}$ \\
\hline E. coli (T10) & 12 & 14 & 15 \\
\hline K.pneumoniae (T10) & 12 & 13 & 15 \\
\hline K.pneumoniae (C103) & 12 & 12 & 14 \\
\hline P.vulgaris (C103) & 11 & 11 & 13.5 \\
\hline E. coli(W14) & 11 & 11 & 15 \\
\hline K.pneumoniae (W14) & 10 & 10 & 12 \\
\hline K. pneumoniae (U8) & 8 & 10 & 11 \\
\hline E. coli(U8) & 11 & 11 & 12 \\
\hline K. pneumoniae (T7) & 10 & 12 & 12 \\
\hline E. coli (T7) & 10 & 11 & 11.5 \\
\hline K. pneumoniae (IP11) & 11 & 12 & 13 \\
\hline
\end{tabular}

T10, C103, W14, U8, T7 and IP11 are strains of Enterococcus species as defined in Table 1; A, B and C are concentrations of AgNPs of 60, 80 and $100 \mu \mathrm{g} / \mathrm{ml}$ respectively; each value is average of two readings. free extracts of Enterococcus sp. can be applied for the biogenic and eco-friendly synthesis of AgNPs, which adds to the biotechnological relevance of the bacterial isolates.

\section{Antimicrobial activities of biosynthesized AgNPs}

The biosynthesized AgNPs showed inhibitory activities against some clinical isolates of bacteria (Table 2). The AgNPs at concentrations of $60-100 \mu \mathrm{g} / \mathrm{ml}$ inhibited the growth of multi-drug resistant strains of $E$. coli, $P$. vulgaris and $\mathrm{K}$ pneumoniae with zones of inhibition of $8-15 \mathrm{~mm}$. The limited inhibitory actions might be due to the multidrug resistant nature of the isolates used in the present study. The antibiotic susceptibility of the isolates showed the drug resistance patterns as follow: $K$. pneumoniae (Caz, Crx, Gen, Cpr, Ofl, Aug, Amp), E. coli (Caz, Crx, Gen, Cpr, Ofl, Aug, Nit, Amp) and P. vulgaris (Caz, Crx, Cpr, Ofl, Aug, Nit, Amp). The results are in agreement with earlier published works on the antibacterial activities of AgNPs (Salem et al., 2014; Shankar et al., 2014; Lateef et al., 2015a, b, d; Lateef et al., 2016a, e). In a similar work, Chandrakanth et al. (2014) reported inhibitory zones of 14$19 \mathrm{~mm}$ by AgNPs biosynthesized using Enterococcus faecium
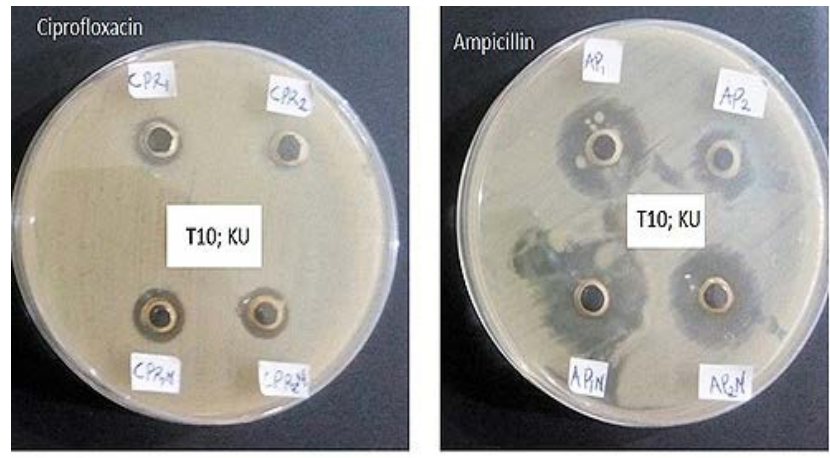

Fig. 5. The synergistic activities of biosynthesized AgNPs with antibiotics on some clinical bacterial isolates
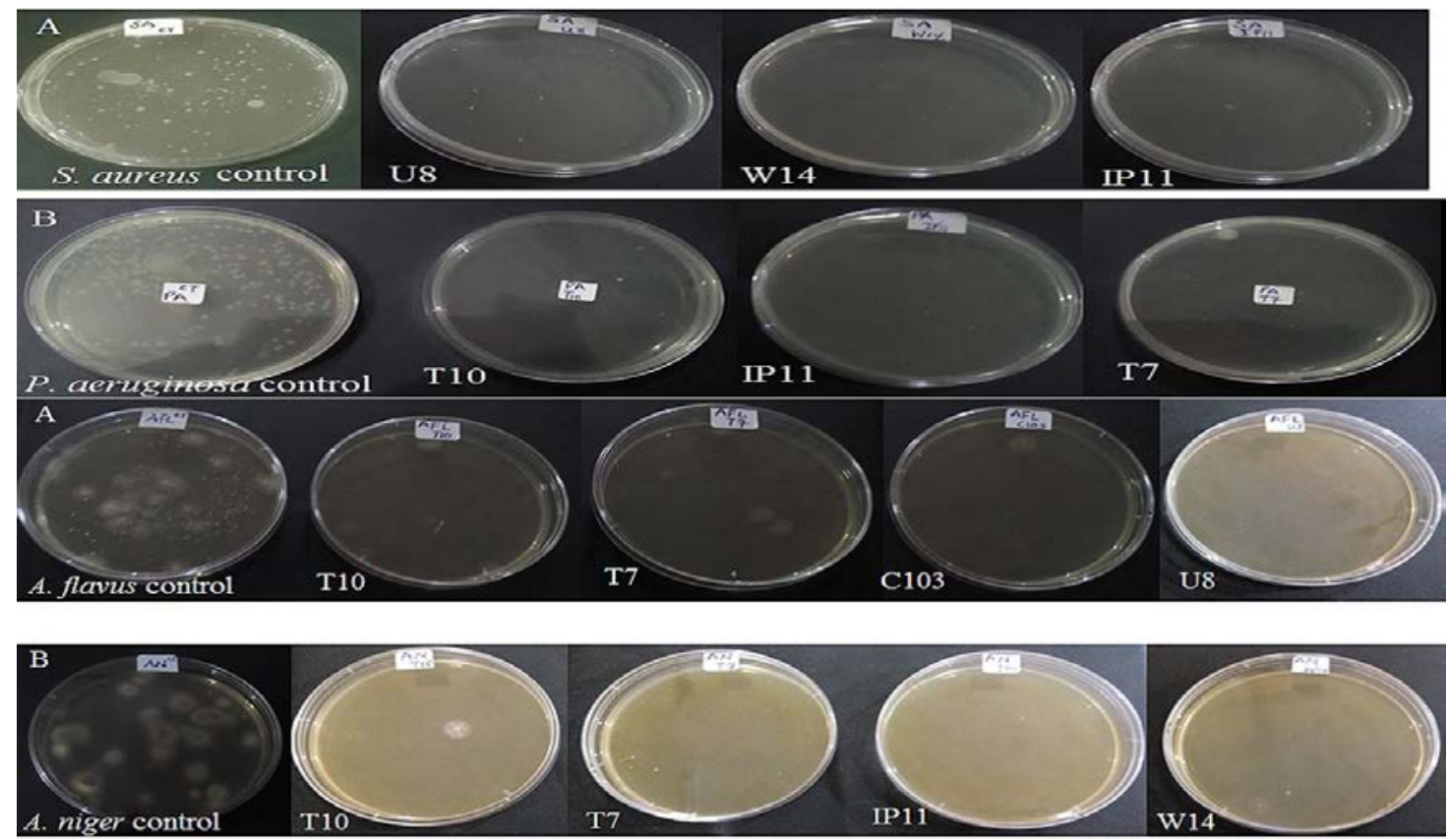

Fig. 6. The antibacterial and antifungal activities of biosynthesized AgNPs as additives in emulsion paint 
against multi-drug resistant strains of $E$. coli, K. pneumoniae and $S$. aureus.

In AgNPs-antibiotics synergistic studies, it was discovered that the presence of AgNPs led to the improved performance of antibiotics such as ampicillin, ciprofloxacin and cefuroxime against drug-resistant strains of $K$. pneumoniae. Improved performance of 13.6-71.4, 8.3-57.1 and $71.4-85.7 \%$ were obtained for ampicillin, ciprofloxacin and cefuroxime respectively when used in combination with AgNPs (Fig. 5). It is noteworthy that in most cases, the two levels of antibiotic concentrations of 0.5 and $1 \mathrm{mg} / \mathrm{ml}$ used alone did not inhibit the growth of the test isolates. Therefore, the inclusion of AgNPs might have rendered the isolates susceptible, either by acting as drug carrier or by enhancing entry of antibiotics as a result of damage to the bacterial cell wall. These results are similar to those previously reported (Devi and Joshi, 2012; Lateef et al., 2015a; Lateef et al., 2016b; Lateef et al., 2016e) on the synergistic antibacterial effects of AgNPs on some antibiotics against Gram positive and negative bacteria. The susceptibility of drug-resistant bacteria as offered by AgNPsantibiotics synergy could be a promising panacea to solving problems of curtailing the prevalent drug-resistance phenomenon among bacteria in clinical practice (Lateef $e t$ al., 2005).

Similarly, the incorporation of biosynthesized AgNPs into emulsion paint yielded pronounced antimicrobial efficacy, which has potential of protecting the paint against microbial attack and biodeterioration. Remarkable antibacterial and antifungal activities were noticed through the drastic reduction of growth of $S$. aureus, $P$. aeruginosa, $A$. niger and $A$. flavus leading to the appearance of a single or few colonies after $72 \mathrm{~h}$ of incubation as against dense growth that were obtained on the control plates (Fig. 6). The results are in agreement with those reported earlier (Lateef et al., 2015a; Lateef et al., 2016b; Lateef et al., 2016e). It is envisaged that the AgNPs can act as nanopreservative in paint to prevent microbial deterioration thereby extending the shelf life of paints and painted surfaces.

\section{Conclusions}

In the current study, green synthesis of AgNPs using the cell-free extracts of six strains of Enterococcus species was successfully carried out. The spherical biosynthesised AgNPs of 4-55 nm in size displayed good antibacterial activities against multi-drug resistant strains of bacteria in both single and synergistic studies. The antimicrobial properties of the particles were demonstrated in paint, resulting to elimination of $S$. aureus, $P$. aeruginosa, $A$. niger and $A$. flavus when the particles were used as additives. The study has shown the relevance of Enterococcus species as biotechnological tool in the green synthesis of AgNPs.

\section{Acknowledgements}

The provision of some of the facilities used in this study by the authority of LAUTECH, Ogbomoso, is gratefully acknowledged.

\section{References}

Adelere IA, Lateef A (2016). A novel approach to the green synthesis of metallic nanoparticles: the use of agro-wastes, enzymes and pigments. Nanotechnology Reviews (6):567-587.

Anandalakshmi K, Venugobal J, Ramasamy V (2016). Characterization of silver nanoparticles by green synthesis method using Pedalium murex leaf extract and their antibacterial activity. Applied Nanoscience 6:399-408.

Andrews JM (2005). BSAC standardized disc susceptibility testing method (version 4). Journal of Antimicrobial Chemotherapy 56:60-76

Ashajyothi CM, Manjunath NR, Chandrakanth KR (2014). Antibacterial activity of biogenic Zinc oxide nanoparticles synthesized from Enterococcusfaecalis. International Journal of ChemTech Research 6:3131-3136.

Ashajyothi C, Chandrakanth RK (2014). Biological synthesis and characterization of gold nanoparticles from Enterococcus faecalis. Journal of Bionanoscience 8:255-259.

Azeez MA, Lateef A, Asafa TB, Yekeen TA, Akinboro A, Oladipo IC, Gueguim-Kana EB, Beukes LS (2017). Biomedical applications of cocoa bean extract-mediated silver nanoparticles as antimicrobial, larvicidal and anticoagulant agents. Journal of Cluster Science 28(1) 149-164.

Blast (2016). Retrieved 14 February 2016 from http://blast.ncbi.nlm. nih.gov.

Chandrakanth RK, Ashajyothi C, Oli AK, Prabhurajeshwar C (2014) Potential bactericidal effect of silver nanoparticles synthesised from Enterococcus species. Oriental Journal of Chemistry 30:1253-1262.

Choi O, Deng KK, Kim NJ, Ross L, Surampalli RY, Hu Z (2008). The inhibitory effects of silver nanoparticles, silver ions, and silver chloride colloids on microbial growth. Water Resources 42:30663074.

Chortyk TO, Severson RF, Cutler HC, Siesson VA (1993). Antibiotic activities of sugar esters isolated from selected Nicotiana species. Bioscience Biotechnology Biochemistry 57:1355-1356.

Das VL, Thomas R, Varghese RT, Soniya EV, Mathew J, Radhakrishnan EK (2014). Extracellular synthesis of silver nanoparticles by the Bacillus strain CS 11 isolated from industrialized area. 3 Biotech 4:121-126.

Devi LS, Joshi SR (2012). Antimicrobial and synergistic effects of silver nanoparticles synthesized using soil fungi of high altitudes of Eastern Himalaya. Mycobiology 40:27-34.

Duran N, Marcarto PD, De Souza GIH, Alves OL, Esposito E (2007). Antibacterial effect of silver nanoparticles produced by fungal process on textile fabrics and their effluent treatment. Journal Biomedical Nanotechnology 3:203-208.

Emeka EE, Ojiefoh OC, Aleruchi C, Hassan LA, Christiana OM, Rebecca M, Dare EO, Temitope AE (2014). Evaluation of antibacterial activities of silver nanoparticles green-synthesized using pineapple leaf(Ananas comosus). Micron 57:1-5.

Gong P, Li H, He X, Wang K, Hu J, Tan W, Zhang S, Yang X (2007). Preparation and antibacterial activity of $\mathrm{Fe}_{3} \mathrm{O}_{4}$ and $\mathrm{Ag}$ nanoparticles. Nanotechnology 18:604-611. 
202

Joerger R, Klaus T, Granqvist CG (2000). Biologically produced silvercarbon composite materials for optically functional thin-film coatings. Advanced Materials 12:407-409.

Kannan RRR, Arumugam R, Ramya D, Manivannan K, Anantharaman P (2013). Green synthesis of silver nanoparticles using marine macroalga Chaetomorpha linum. Applied Nanoscience 3:229-233.

Kathiraven T, Sundaramanickam A, Shanmugam N, Balasubramanian $\mathrm{T}$ (2015). Green synthesis of silver nanoparticles using marine algae Caulerpa racemosa and their antibacterial activity against some human pathogens. Applied Nanoscience 5:499-504.

Lateef A, Adelere IA, Gueguim-Kana EB, Asafa TB, Beukes LS (2015b). Green synthesis of silver nanoparticles using keratinase obtained from a strain of Bacillus safensis LAU 13. International Nano Letters 5:29-35.

Lateef A, Oloke JK, Gueguim-Kana EB (2005). The prevalence of bacterial resistance in clinical, food, water and some environmental samples in Southwest Nigeria. Environmental Monitoring and Assessment 100:59-69.

Lateef A, Adelere IA, Gueguim-Kana EB (2015c). The biology and potential biotechnological applications of Bacillus safensis. Biologia 70:411-419.

Lateef A, Adeeyo AO (2015). Green synthesis and antibacterial activities of silver nanoparticles using extracellular laccase of Lentinus edodes. Notulae Scientia Biologicae 7:405-411.

Lateef A, Azeez MA, Asafa TB, Yekeen TA, Akinboro A, Oladipo IC, Azeez L, Ajibade SE, Ojo SA, Gueguim-Kana EB, Beukes LS (2016a). Biogenic synthesis of silver nanoparticles using a pod extract of Cola nitida: antibacterial, antioxidant activities and application as a paint additive. Journal of Taibah University of Science 10:551-562.

Lateef A, Azeez MA, Asafa TB, Yekeen TA, Akinboro A, Oladipo IC, Azeez L, Ojo SA, Gueguim-Kana EB, Beukes LS (2016b). Cocoa pod extract-mediated biosynthesis of silver nanoparticles: Its antimicrobial, antioxidant and larvicidal activities. Journal of Nanostructure in Chemistry 6:159-169.

Lateef A, Azeez MA, Asafa TB, Yekeen TA, Akinboro A, Oladipo IC, Ajetomobi FE, Gueguim-Kana, EB, Beukes LS (2015d). Cola nitida-mediated biogenic synthesis of silver nanoparticles using seed and seed shell extracts and evaluation of antibacterial activities. BioNanoScience 5:196-205.

Lateef A, Ojo MO (2016). Public health issues in the processing of cassava (Manihot esculenta) for the production of 'lafun' and the application of hazard analysis control measures. Quality Assurance and Safety of Crops and Foods 8:165-177.

Lateef A, Ojo SA, Akinwale AS, Azeez L, Gueguim-Kana EB, Beukes, LS (2015a). Biogenic synthesis of silver nanoparticles using cell-free extract of Bacillus safensis LAU 13: antimicrobial, free radical scavenging and larvicidal activities. Biologia 70:1295-1306.

Lateef A, Ojo SA, Azeez MA, Asafa TB, Yekeen TA, Akinboro A, Oladipo IC, Gueguim-Kana EB, Beukes LS (2016e). Cobweb as novel biomaterial for the green and ecofriendly synthesis of silver nanoparticles. Applied Nanoscience 6:863-874.
Lateef A, Akande MA, Azeez MA, Ojo SA, Folarin BI, Gueguim-Kana EB, Beukes LS (2016c). Phytosynthesis of silver nanoparticles (AgNPs) using miracle fruit plant (Synsepalum dulcificum) for antimicrobial, catalytic, anti-coagulant and thrombolytic applications. Nanotechnology Reviews 5(6):507-520.

Lateef A, Akande MA, Ojo SA, Folarin BI, Gueguim-Kana EB, Beukes LS (2016f). Paper wasp nest-mediated biosynthesis of silver nanoparticles for antimicrobial, catalytic, anti-coagulant and thrombolytic applications. 3Biotech 6:140.

Lateef A, Ojo SA, Elegbede JA (2016g). The emerging roles of arthropods and their metabolites in the green synthesis of metallic nanoparticles. Nanotechnology Reviews 5(6):601-622

Lateef A, Ojo SA, Oladejo SM (2016d). Anti-candida, anti-coagulant and thrombolytic activities of biosynthesized silver nanoparticles using cell-free extract of Bacillus safensis LAU 13. Process Biochemistry 51:1406-1412.

Magudapathy P, Gangopadhyay P, Panigrahi BK, Nair KGM, Dhara S (2001). Electrical transport studies of Ag nanoclusters embedded in glass matrix. Physica B 299:142-146.

Malarkodi C, Annadurai G (2012). A novel biological approach on extra synthesis and characterization of semiconductor Zinc sulfide nanoparticles. Applied Nanoscience 3:389-395.

Malarkodi C, Chitra K, Rajeshkumar S, Paulkumar K, Gnanajobitha G, Vanaja M, Annadurai G (2013). Novel eco-friendly synthesis of titanium oxide nanoparticles by using Planomicrobium sp, and evaluation of its antimicrobial activity. Der Pharmacia Sinica 4:5966.

Mulvaney P (1996). Surface plasmon spectroscopy of nanosized metal particles. Langmuir 12:788-800.

Netala VR, Kotakadi VS, Domdi L, Gaddam SA, Bobbu P, Venkata SK, Ghosh SB, Tartte V (2016). Biogenic silver nanoparticles: efficient and effective antifungal agents. Applied NanoBioscience 6: 475-484.

Ojo SA, Lateef A, Azeez MA, Oladejo SM, Akinwale AS, Asafa TB, Yekeen TA, Akinboro A, Oladipo IC, Gueguim-Kana EB, Beukes LS (2016). Biomedical and catalytic applications of gold and silvergold alloy nanoparticles biosynthesized using cell-free extract of Bacillus safensis LAU 13: antifungal, dye degradation, anti-coagulant and thrombolytic activities. IEEE Transactions on NanoBioscience 15: 433-442.

Oladipo IC, Sanni A, Swarnakar S (2013). Phenotypic and genomic characterization of Enterococcus species from some Nigerian fermented foods. Food Biotechnology 27:39-53.

Oladipo IC, Sanni A, Swarnakar S (2014a). Virulence potential of Enterococcus gallinarum strains isolated from selected Nigerian traditional fermented foods. Journal of Bioscience and Biotechnology 3:97-104.

Oladipo IC, Sanni AI, Chakraborty W, Chakravorty S, Jana S, Rudra DS, Gacchui R, Swarnakar S (2014b). Bioprotective potential of bacteriocinogenic Enterococcus gallinarum strains isolated from some Nigerian fermented foods, and of their bacteriocins. Polish Journal of Microbiology 63:415-422.

Oladipo IC, Sanni AI, Chakraborty W, Chakravorty S, Jana S, Rudra 
DS, Gacchui R, Swarnakar S (2015). Technological properties of strains of Enterococcus gallinarum isolated from selected Nigerian traditional fermented foods. Malaysian Journal of Microbiology 11:1-13.

Pollmann M, Nordhoff M, Pospischil A, Tedin K, Wieler LH (2005). Effects of a probiotic strain of Enterococcus faecium on the rate of natural Chlamydia infection in swine. Infection and Immunity 73:4346-4353.

Priyadarshini S, Gopinath V, Priyadharsshini NM, Ali DM, Velusamy P (2013). Synthesis of anisotropic silver nanoparticles using novel strain, Bacillus flexus and its application. Colloids Surfaces B 102:232-237.

Rajeshkumar S, Kannan C, Annadurai G (2013). Synthesis and characterization of antimicrobial silver nanoparticles using marine brown seaweed Padina tetrastromatica. Drug Invention Today 4:511-513.

Rajeshkumar S, Ponnanikajamideen M, Malarkodi C, Malini M, Annadurai G (2014). Microbe-mediated synthesis of antimicrobial semiconductor nanoparticles by marine bacteria. Journal of Nanostructure in Chemistry 4:1-7.

Salem WM, Haridy M, Sayed WF, Hassan NH (2014). Antibacterial activity of silver nanoparticles synthesized from latex and leaf extract of Ficus sycomorus. Industrial Crops and Products 62:228-234.

Selvi KV, Sivakumar T (2012). Isolation and characterization of silver nanoparticles from Fusarium oxysporium. International Journal of Current Microbiology and Applied Science 1:56-62.
Shaligram NS, Bule M, Bhambure R, Singhal RS, Singh SK, Szakacs G, Pandey A (2009). Biosynthesis of silver nanoparticles using aqueous extract from the compacting producing fungal strain. Process Biochemistry 44:939-943.

Shameli K, Ahmad MB, Zargar M, Wan Yunus WMZ, Ibrahim NA, Sha-banzadeh P, Ghaffari-Moghadam M (2011). Synthesis and characterization of silver/montmorillonite /chitosan bionanocomposites by chemical reduction method and their antibacterial activity. International Journal of Nanomedicine 6:271284.

Shankar S, Jaiswal L, Aparna RSL, Prasad RGSV (2014). Synthesis, characterization, in vitro biocompatibility, and antimicrobial activity of gold, silver and gold silver alloy nanoparticles prepared from Lansium domesticum fruit peel extract. Materials Letters 137:75-78.

Sneha K, Sathishkumar M, Lee SY, Bae MA, Yun YS (2011). Biosynthesis of $\mathrm{Au}$ nanoparticles using cumin seed powder extract. Journal of Nanoscience Nanotechnology 11:1811-1814.

Tompkins TA, Hagen KE, Wallace TD, Fillion-Forte V (2008). Safety evaluation of two bacterial strains used in Asian probiotic products. Canadian Journal of Microbiology 54:391-400.

Vankerckhoven V, Huys G, Vancanneyt M, Snauwaert C, Swings J, Klare I, Witte W, Van Autgaerden T, Chapelle S, Lammens C, Goossens H (2008). Genotypic diversity, antimicrobial resistance and virulence factors of human isolates and probiotic cultures constituting two intra specific groups of Enterococcus faecium isolates. Applied and Environmental Microbiology 74:4247-4255. 